\title{
Means of Information and Media and the Influence for the Practice of Physical Activity
}

\author{
Cristina Bonoto Vieira Da Cunha ${ }^{1 *}$, Ingi Petitemberte Klain ${ }^{2}$, Airton José Rombaldi², \\ José Carlos Leitão ${ }^{1}$ \\ ${ }^{1}$ University of Trás-os-Montes and Alto Douro (UTAD), Vila Real, Portugal \\ ${ }^{2}$ Federal University of Pelotas (UFPel), Pelotas, Brasil \\ Email: *cristinabonoto@hotmail.com, Ingiklain@yahoo.com.br
}

How to cite this paper: Da Cunha, C.B.V., Klain, I.P., Rombaldi, A.J. and Leitão, J.C. (2018) Means of Information and Media and the Influence for the Practice of Physical Activity. Open Access Library Journal, 5: e4635.

https://doi.org/10.4236/oalib.1104635

Received: May 3, 2018

Accepted: May 18, 2018

Published: May 21, 2018

Copyright $\odot 2018$ by authors and Open Access Library Inc.

This work is licensed under the Creative Commons Attribution International License (CC BY 4.0).

http://creativecommons.org/licenses/by/4.0/

\section{Open Access}

\begin{abstract}
The purpose of this study was to verify which means of information has the most influence for the practice of physical activity among fitness centers goers. The sample consisted of 299 individuals of both genders, in the age range of 16 to 50 years old. A biosociodemographic questionnaire was used to collect data on gender, age, educational level, socioeconomic level and means of access to information. The scores obtained with this research were typed in spreadsheet and later transferred to the statistical package SPSS version 17.0 for Windows where they received statistical treatment. Of the total number of respondents, $62.2 \%$ were female; the majority were aged between 16 and 30 years (63.2\%); in the most prevalent category, those were graduated at university (46.8\%); and $85.3 \%$ belonged to social strata A and B. In relation to the media that most influenced them to practice physical activity, the internet ranked first $(84.95 \%)$, followed by television $(83.95 \%)$, newspaper $(50.84 \%)$, radio $(45.48 \%)$, magazines $(23.08 \%)$ and others $(4.35 \%)$.
\end{abstract}

\section{Subject Areas}

Kinesiology

\section{Keywords}

Means of Information, Physical Activity, Fitness Centers

\section{Introduction}

The desire to change something in physical appearance is increasing, especially the weight, because we live a culture that preaches that good appearance is synonymous of success, health and determination. The media sells the perfection so 
sought after, but masked by photoshop and untruths [1].

The pressures of modern society through the means of information highlight that we need to be leaner, stronger, with a well defined body, without wrinkles, young and beautiful [2]. Damasceno [1] reports that the relation with the body is influenced by various sociocultural factors, which makes men and women seek a better physical appearance. Alvarenga [2] confirms that the individual is strongly influenced by the environment where he lives.

Silva [3] states that the culturally chosen places to seek an athletic body and aesthetically accepted by our society are fitness centers. Thus, the present study had as objective to verify which means of information has the most influence for the practice of physical activity among fitness centers goers.

\section{Methodology}

This study was characterized as descriptive and transversal. The sample consisted of 299 individuals of both genders, goers of eight fitness centers in the central zone of the city of Passo Fundo, located in the north of the State of Rio Grande do Sul, Brazil. The eight fitness centers together totaled 1.580 individuals practicing physical activity and personalized training, which corresponds to the universe of this research and were chosen for their central position and for having a larger number of goers, which has favored reaching the objective of the present study.

The subjects were recruited randomly, characterizing a probabilistic sample.

The applied methodology was approved by the Human Research Ethics Committee of the Passo Fundo University, Rio Grande do Sul, Brazil, under opinion no. 261-2/2009 and the data were collected after the subjects had signed the Free and Informed Consent Term, authorizing their participation in the methodology and agreeing with the disclosure of the results, keeping the personal identities.

The owners of the fitness centers also agreed and authorized the research in their accommodations.

The study has included individuals aged between 16 and 50 years old and excluded those with special needs-physical or neurological—who were illiterate and pregnant. This exclusion is justified because pregnant women and people with special needs are more prone to distortions as to their body image, while illiterates would have difficulty to read the questionnaire and the reading by the applicators could embarrass them, since some questions were personal mark.

To collect data referring to gender, age, educational level, socioeconomic level and means of access to information, a biossociodemographic questionnaire has been used based on the Brazilian Association of Research Companies. The variable age was categorized into five groups: 16 to 20 years old; 21 to 30 years old; 31 to 40 years old; 41 to 50 years old; more than 50 years old. The categories of variable of education level were: complete elementary education; complete high school; incomplete higher education; complete higher education; Post-graduation Lato Sensu and Post-graduation Stricto Sensu. The socioeconomic level ex- 
pressed income in five categories: A (highest); B; C; D and E (lowest).

Regarding the means of access to information, respondents should answer yes (1) or no (0) about the influence of the main media to practice physical activity, such as television, internet, newspaper, radio, magazine and others. Face to the questionnaire, the participant answered by pointing out the best answer.

The scores obtained with this research were typed in spreadsheet and later transferred to the statistical package SPSS version 17.0 for Windows where they received statistical treatment.

\section{Results}

Of the 299 subjects included in the study, 62.2\% were female; the majority were aged between 16 and 30 years old (63.2\%); in the most prevalent category, were those with incomplete or complete higher education (46.8\%); and $85.3 \%$ belonged to classes A and B (Table 1 ).

Regarding to the means of information which have most influenced to the practice of physical activity, respondents demonstrated that the Internet is the media that has the most influence over their decision (84.95\%), followed by television $(83.95 \%)$, newspaper $(50.84 \%)$, radio $(45.48 \%)$, magazines $(23.08 \%)$ and others (4.35\%) (Table 2).

Table 1. Sociodemographic characteristics of the sample $(\mathrm{n}=299)$.

\begin{tabular}{|c|c|}
\hline Variables & $\mathrm{n}(\%)$ \\
\hline \multicolumn{2}{|l|}{ Gender } \\
\hline Female & $186(62.2 \%)$ \\
\hline Male & $113(37.8 \%)$ \\
\hline \multicolumn{2}{|l|}{ Age group } \\
\hline $16-20$ & $55(18.4 \%)$ \\
\hline $21-30$ & $134(44.8 \%)$ \\
\hline $31-40$ & $68(22.7 \%)$ \\
\hline $31-40$ & $40(13.4 \%)$ \\
\hline $41-50$ & $1(0.3 \%)$ \\
\hline \multicolumn{2}{|l|}{ Schooling } \\
\hline Complete primary education & $22(7.4 \%)$ \\
\hline Complete high School & $39(13.0 \%)$ \\
\hline Incomplete higher education & $75(25.1 \%)$ \\
\hline Complete higher Education & $65(21.7 \%)$ \\
\hline Postgraduate Lato Sensu & $64(21.4 \%)$ \\
\hline Postgraduate Stricto Sensu & $31(10.4 \%)$ \\
\hline \multicolumn{2}{|l|}{ Socioeconomic level } \\
\hline $\mathrm{D}$ & $1(0.3 \%)$ \\
\hline $\mathrm{C}$ & $24(8 \%)$ \\
\hline B & $93(31.1 \%)$ \\
\hline A & $162(54.1 \%)$ \\
\hline
\end{tabular}

Values express absolute and relative frequency. 
Table 2. Influence of the media for the practice of physical activity.

\begin{tabular}{cc}
\hline Media & Statistics \\
\hline Internet & $254(84.95 \%)$ \\
TV & $251(83.95 \%)$ \\
Newspaper & $152(50.84 \%)$ \\
Radio & $136(45.48 \%)$ \\
Magazines & $69(23.08 \%)$ \\
Others & $13(4.35 \%)$ \\
\hline
\end{tabular}

\section{Discussion}

The family, interrelated groups and the media are the major influences on the body Image development in the adolescence [4]. In adulthood, according to Damasceno [1], dissatisfaction with body image increases as the media exposes beautiful bodies, which has provoked a compulsion to search for the ideal anatomy through physical activity. According to Lopes et al. [5] among the elderly, the messages conveyed by the media create the stereotype of a young, healthy, active senior citizen who breaks with the idea of old age. Then, the media has an important role in adherence to the practice of physical activity.

Anzai [6], Martin \& Lichtenberger [7] and Hansen \& Vaz [8] emphasize that researches attempt to confirm that the practice of physical activity is associated to improved body image. Williams \& Cash [9] confirm that an exercise program can lead to modest changes, around less than $10 \%$ of variation in body image scores.

According to Silva [3], fitness centers are full of individuals in search of ideal bodies according to the standards of beauty established by society and constantly passed on by the means of information.

In this sense, Tahara, Schwartz \& Silva [10] have analyzed the main factors of the adherence and maintenance of programs of regular physical exercises, carried out in fitness centers, and concluded that, with regard to the stimuli for the beginning of the practice of physical activity in fitness centers, the majority of respondents received encouragement from the family (33\%) and the media (33\%) to start an exercise program.

Once it was established that the media has a great influence on the perception of the body image and the ability to motivate people to practice physical activity in order to harmonize themselves with their bodies, it is important to analyze among the communication tools, which has more influence on the decision of entering a training program.

There are many studies that show that the media, with the exaggerated focus on the cult of body shape, can be an aggravating factor in the way people perceive themselves, increasing their dissatisfaction with their bodies [11] [12] [13]. This greater dissatisfaction with body image is a reflection of the pressure exerted by the media, dictating patterns of beauty marked by excessive thinness 
and by body values [14] [15] [16] based on catwalk models and actresses who adopt this standard [1]. Therefore, the media has frequently contributed to the appearance of psychic appearance disorders, such as vigorexia, of eating disorders such as anorexia nervosa and bulimia [17], because the body is considered as a locus of expression and valorization of aesthetics [18].

However, the first limitation that this study has faced was the lack of research that demonstrates which media has more influence on individuals when it is related to the adherence of a physical activity. However, in a similar survey, Rizzini et al. [19], analyzing the influence of television, video games, computer games, internet and cell phones in adolescents' lives, concluded that television is the mean of mass communication that has the most impact, followed by the computer and the internet. In this study, it was found out that the Internet is the media resource that has the most influence on the decision to practice physical activity (84.95\%), followed by television $(83.95 \%)$ and other media such as newspaper (50.84\%), radio (45.48\%), magazines (23.08\%) and others (4.35\%).

Corroborating with this study of Frois, Moreira \& Stengel [20] point out that television and the internet have mainly influenced the dissemination and appreciation of the sculpted and shaped perfect body, masking the marks of time and experiences of the subject. The media, through websites of beauty agencies, virtual communities, among others, value the cult to the muscles and the conquest of leaner and rejuvenated bodies, as a message of status and perfection, images not always consistent with the stereotype of the viewer. Levy [21] also states that the internet and television are important formative vehicles and constituents of the individual.

In the study by Lopes et al. [5], entitled the Internet as an instrument to encourage physical activities and improve the quality of life of the elderly, to $8 \%$ of respondents, information available on the internet, among other issues, encourage physical exercise, to an improvement in their quality of life.

Vargas et al. [22], seeking to analyze the influence of the media on people's lifestyle regarding to the practice of physical activity, food, smoking and alcohol consumption, have attested that $70.6 \%$ of those interviewed had some kind of media memory related to the benefits of physical activity. Yet, $89.6 \%$ of the respondents still believed that the media influences behavior change. However, the authors have treated media as advertisement, news or program, not separating by segment.

Different results have been found by Silva, Both \& Real [23], in a study that sought to relate the media where the interviewed most obtained information about bodybuilding, concluding that the most used media is the magazine (32.5\%), followed and sharing a large part of the answers by television (29\%) and internet (29\%), others such as posters and folders (6.5\%), newspapers (3\%) and nothing to the radio.

The result of this study is justified by the fact that most of the included individuals were between 16 and 30 years old of age (63.2\%), incomplete or complete higher education (46.8\%) and belong to social strata A and B (85.3\%). It is un- 
derstood that these characteristics were determinant for the internet media to have figured in the first place regarding the influence for the practice of physical activity, since it is a public that constantly accesses the internet and is the focus of many advertising campaigns in this environment. But it is observed that the television (83.95\%) still remains in the first positions when the subject is influence of the viewers.

One limitation of this study is that the sample was not representative of users of fitness centers in the city of Passo Fundo, due to the fact that only city centers were chosen, which makes it difficult to generalize the results.

With the emergence and popularization of the internet, television has ceased to be the most used media for advertising, but it still has a great publicity appeal for gathering images and sounds and thus being able to express feelings and direct behaviors.

Thus, the results suggest that the internet and television are the media that most influenced the sample studied to enter a physical exercise program, interfering with the way people see their own bodies, accentuating feelings of dissatisfaction with appearance and motivating them to get better physical shape in the fitness centers.

\section{Conflict of Interest}

The authors declare that there isn't conflict of interest.

\section{References}

[1] Damasceno, V.O., et al. (2006) Body Image and Ideal Body. Revista Brasileira de Ciência e Movimento, 14, 87-96.

[2] Alvarenga, M.S., Philippi, S.T., Lourenço, B.H., et al. (2010) Dissatisfaction with Body Image in Brazilian University Students. Jornal Brasileiro De Psiquiatria, 59, 44-51. https://doi.org/10.1590/S0047-20852010000100007

[3] Silva, A.M. (1999) The Body of the World: Reflections about Body Expectancy in Modernity. Master's Dissertation, Center for Philosophy and Sciences, Federal University of Santa Catarina.

[4] Weinshenker, N. (2002) Adolescence and Body Image. School Nurse News, 19, 12-16.

[5] Lopes, C., et al. (2008) The Internet as an Instrument to Encourage physical Activities and to improve the Quality of Life for the Elderly. Digital Magazine-Buenos Aires, 13.

[6] Anzai, K. (2000) The Body as Object of Consumption. Revista Brasileira de Ciências do Esporte, 21, 71-76.

[7] Martin, K.A. and Lichtenberger, C.M. (2002) Fitness Enhancement and Changes in Body Image. In: Cash, T.F. and Prusinky, T., Eds., Body Image: A Handbook of Theory, Research, and Clinical Practive, Guilford Press, New York, 47, 414-421.

[8] Hansen, R. and Vaz, A.F. (2004) Training, Worship and Beautification of the Body: A Study in Gyms and Bodybuilding. Revista Brasileira de Ciências do Esporte, 26, 135-152.

[9] Williams, P.A. and Cash, T.F. (2001) Effects of a Circuit Weight Training Program 
on the Body Images of College Students. International Journal of Eating Disorders, 30, 75-82. https://doi.org/10.1002/eat.1056

[10] Tahara, A.K., Schwartz, G.M. and Silva, K.A. (2003) Adherence and Maintenance of the Practice of Exercises in Academies. Revista Brasileira de Ciência e Movimento, 11, 7-12.

[11] Saikali, C.J., et al. (2004) Body Image in Eating Disorders. Revista de Psiquiatria Clínica, 31.

[12] Souto, S. and Ferro-Bucher, J.S.N. (2006) Indiscriminate Practices of Diets and the Development of Eating Disorders. Nutrition Magazine, 19.

[13] Veras, A.L. and Laus, M.F. (2010) Current Body Image Development and Construction: A Cognitive-Behavioral View. Brazilian Journal of Cognitive Therapy, 6.

[14] Petroski, E.L., Pelegrini, A. and Glaner, M.F. (2012) Reasons and Prevalence of Dissatisfaction with Body Image in Adolescents. Science and Collective Health, 17.

[15] Garcia, R.P. and Lemos, K.M. (2003) Aesthetics as a Value in Physical Education. Revista Paulista de Educação Física, 17, 32-40. https://doi.org/10.11606/issn.2594-5904.rpef.2003.138841

[16] Laus, M.F., Costa, TM.B. and Almeida, S.S. (2011) Body Image Dissatisfaction and Its Relationship with Physical Activity and Body Mass Index in Brazilian Adolescents. Jornal Brasileiro de Psiquiatria, 60, 315-320.

[17] Jumberg, M.B. (2007) Beauty through History. In: Son, L.G., Ed., Of Evil with the Mirror. Body Dysmorphic Disorder, AC Pharmaceuticals, Rio de Janeiro.

[18] Pereira, A.L. (2004) For a Phenomenological View of the Contemporary Body: Contribution from the Mountaineering and Gymnastics Academy. Doctoral Thesis, FCDEF-UP, Porto.

[19] Rizzini, I., Pereira, L., Zamora, M.H., Coelho, A.F., Winograd, B. and Carvalho, M. (2005) Brazilian Teens, Media and New Technologies. Revista ALCEU, 6, 41-63.

[20] Frois, E., Moreira, J. and Stengel, M. (2011) Media and Body Image in Adolescence: The Body under Discussion. Psychology under Study, 16.

[21] Levy, P. (1999) Cyberculture. Editora 34, São Paulo.

[22] Vargas, C., et al. (2010) Perception of Adolescents and Adults Regarding the Influence of the Media on Lifestyle. Brazilian Journal of Physical Activity \& Health, 15, 105-110.

[23] Silva, M.A., Both, DR. and Real, M.R.F. (2010) Media and Bodybuilding: Reflexes in the Daily Life of an Academy. Digital Magazine, 15, 144. 